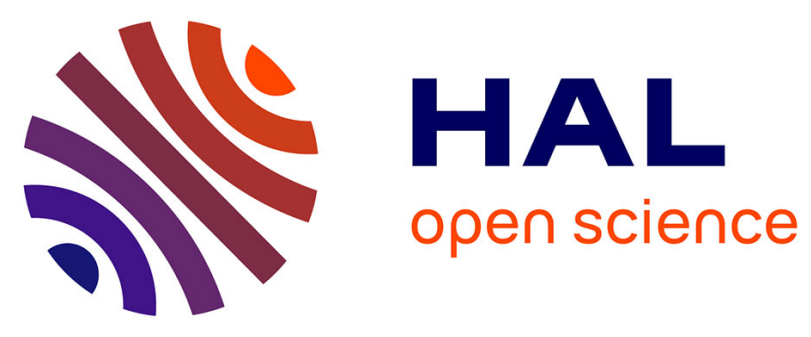

\title{
Understanding and Managing Urban Water in Transition
}

Katherine Daniell, Jean-Daniel Rinaudo, Noel Wai Wah Chan, Céline Nauges, Quentin Grafton

\section{- To cite this version:}

Katherine Daniell, Jean-Daniel Rinaudo, Noel Wai Wah Chan, Céline Nauges, Quentin Grafton. Understanding and Managing Urban Water in Transition. Quentin Grafton; Katherine A. Daniell; Céline Nauges; Jean-Daniel Rinaudo; Noel Wai Wah Chan. Understanding and managing urban water in transition, 15, Springer, pp.1-30, 2015, Global Issues in Water Policy, 978-94-017-9800-6. 10.1007/978-94-017-9801-3_1. hal-01290502

\section{HAL Id: hal-01290502 https://hal.science/hal-01290502}

Submitted on 3 Apr 2020

HAL is a multi-disciplinary open access archive for the deposit and dissemination of scientific research documents, whether they are published or not. The documents may come from teaching and research institutions in France or abroad, or from public or private research centers.
L'archive ouverte pluridisciplinaire HAL, est destinée au dépôt et à la diffusion de documents scientifiques de niveau recherche, publiés ou non, émanant des établissements d'enseignement et de recherche français ou étrangers, des laboratoires publics ou privés. 


\section{Chapter 1}

\section{Understanding and managing urban water in transition}

Katherine A. Daniell, Jean-Daniel Rinaudo, Noel Chan, Céline Nauges and R. Quentin Grafton

\section{Introduction}

Understanding and managing water in the urban context is of vital global importance. Over half the world's population now lives in urban environments (United Nations 2013) and the percentage is set to increase over coming decades. Quality urban living, like life anywhere, requires adequate quantities and qualities of water to support a range of social well-being, economic development, and environmental health. Managing water in cities, along with their linked energy, food, materials, environmental systems, and socio-economic systems is, therefore, an integral component of global sustainability challenges (Sheehan 2007; see also Kenway and Lant, this volume).

These challenges are significant and extremely important; in particular, but not only for, the almost 130 million people globally who do not have access to safe drinking water and 714 million who do not have access to adequate sanitation in urban areas (UNICEF/WHO, 2012). The current global water system is also vulnerable to increasing global water demands, changing urbanisation patterns, and increasing climate risk and uncertainty (e.g. Frederick and Major, 1997; Niemczynowicz, 1999; Vörösmarty et al., 2000; Jenerette and Larsen, 2006). There are different but still substantial challenges in developed countries, where populations are benefiting from high quality water and sanitation services. What is often at stake here is the sustainability of these services, including the social, economic, environmental and governance dimensions of urban water management activities. In line with these challenges, many authors and global institutions consider that there is an urgent need to support the transitions of urban water systems towards more sustainable configurations that can cope with these and other global changes (Larsen and Gujer, 1997; Hellström et al., 2000; Daniell et al., 2005; Mitchell, 2006; UN-WATER, 2012).

The definition of urban water systems and their management that we consider in this book is thus intentionally multi-faceted and includes all components of the urban system where water is a primary concern for managers, residents, community groups and businesses. This includes issues of water 
supply, demand, use, valuation, sanitation systems, storm water management, flood management and management of water dependent ecosystems affected by urban water use, as well as their associated governance structures and processes.

It is the premise of this book that there are a range of changes and transitions occurring in the way water is being managed in many urban settlements around the world. These are taking place as development patterns, climate, social preferences and values are changing, including the relative importance of those related to growing environmental concerns, the financial value of water, social well-being, and the role that access to water and sanitation plays in alleviating poverty.

Here we take the concept of transition to convey the idea of a progressive adaptation or transformation of a system in response to particular stimuli (drivers). Specifically, a transition describes the situation of a system where it lies between points of relative equilibrium. This implies that when a system is "in transition" we can be aware that it is or has rapidly changed from a previous state, but may not be able to predict or know how it will stabilise in the future. Such definitions and understandings of transitions (e.g. Rotmans et al., 2001; Geels 2002; 2004; 2010; Geels and Schot, 2007; van de Brugge and Rotmans, 2007) are based in complex adaptive systems theory (Prigogine and Stengers, 1984; Holland, 1995; Kauffman, 1995; Holling, 2004) and a range of other literature including innovation and technological transitions, governance and evolutionary economics (e.g. Rogers, 1983; Arthur, 1988; Smith et al., 2005; 2010; Sabatier, 1988; Nelson and Winter, 1982).

The future states of a system transitioning towards more sustainable forms of development can be classified in different ways, as for example in van der Brugge and Rotmans (2007), where a system that is transitioning or "taking-off" from one relatively stable state can:

1) have an acceleration of action towards uptake of a new system configuration (e.g. a particular set of urban water innovations or policy alternatives) then stabilise in this new configuration;

2) accelerate like in 1) but before the system has had time to stabilise there is a "backlash" against the new system configuration/options (e.g. which could be caused by a change of government and reform of policies);

3) have some uptake of innovation and system reconfiguration but the extent is limited by previous policy decisions that limit future options or competing innovations-what can be termed as "lock-in" (e.g. large-scale infrastructure policy that would have major economic implications if altered in any significant way over the short-term versus decentralised infrastructure options); and

4) have some limited uptake of innovation/trials of system reconfiguration which are not found to be successful and cause the breakdown of the system (e.g. a supportive environment including regulatory frameworks for a particular innovation or policy option is lacking at the time of attempted implementation).

This implies that for any transition to effectively commence or "take-off" there is need for there to be supportive conditions or a "niche" in which the innovation uptake or new system configuration can be supported. These ideal-type system transition dynamics are represented in 
Figure 1, although we note that these form just one phase of a constantly changing and interconnected complex adaptive system (Holling, 2001). For example, collapse may actually lead to opportunities for positive system re-configuration and transition, as highlighted in the

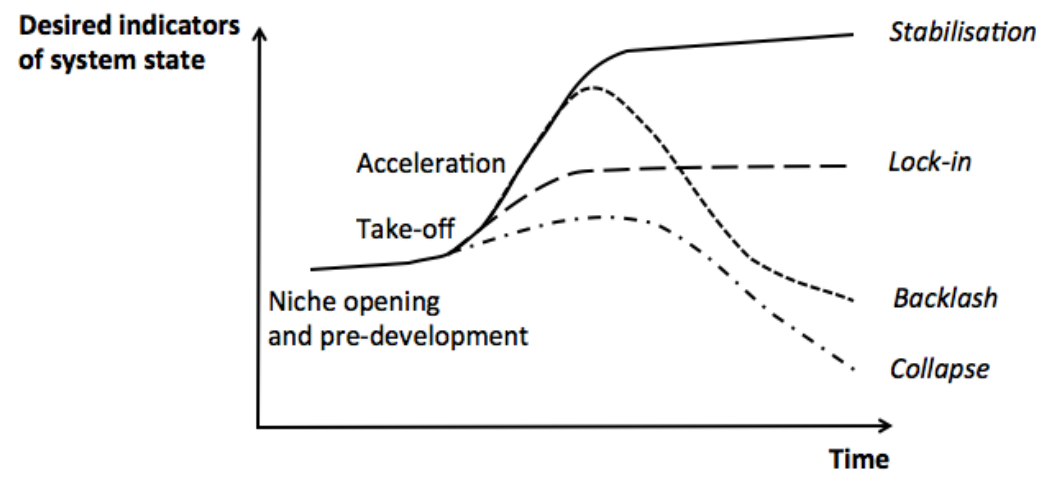

Panarchy framework of complex adaptive social-ecological systems (Gunderson and Holling, 2002).

Figure 1: Complex adaptive system transition pathways to more or less desirable states. Adapted from van der Brugge and Rotmans (2007)

In urban water systems, over time there have been a number of key water system management objectives linked to social values - the equivalent of 'desired indicators of system state' in Figure 1that have driven transitions to different configurations of water systems that are designed to provide specific types of service delivery functions. These water system management objectives and resultant changes in idealised urban water system types have come about as a result of a number of socioeconomic, environmental and governance-related drivers as represented in Figure 2. 


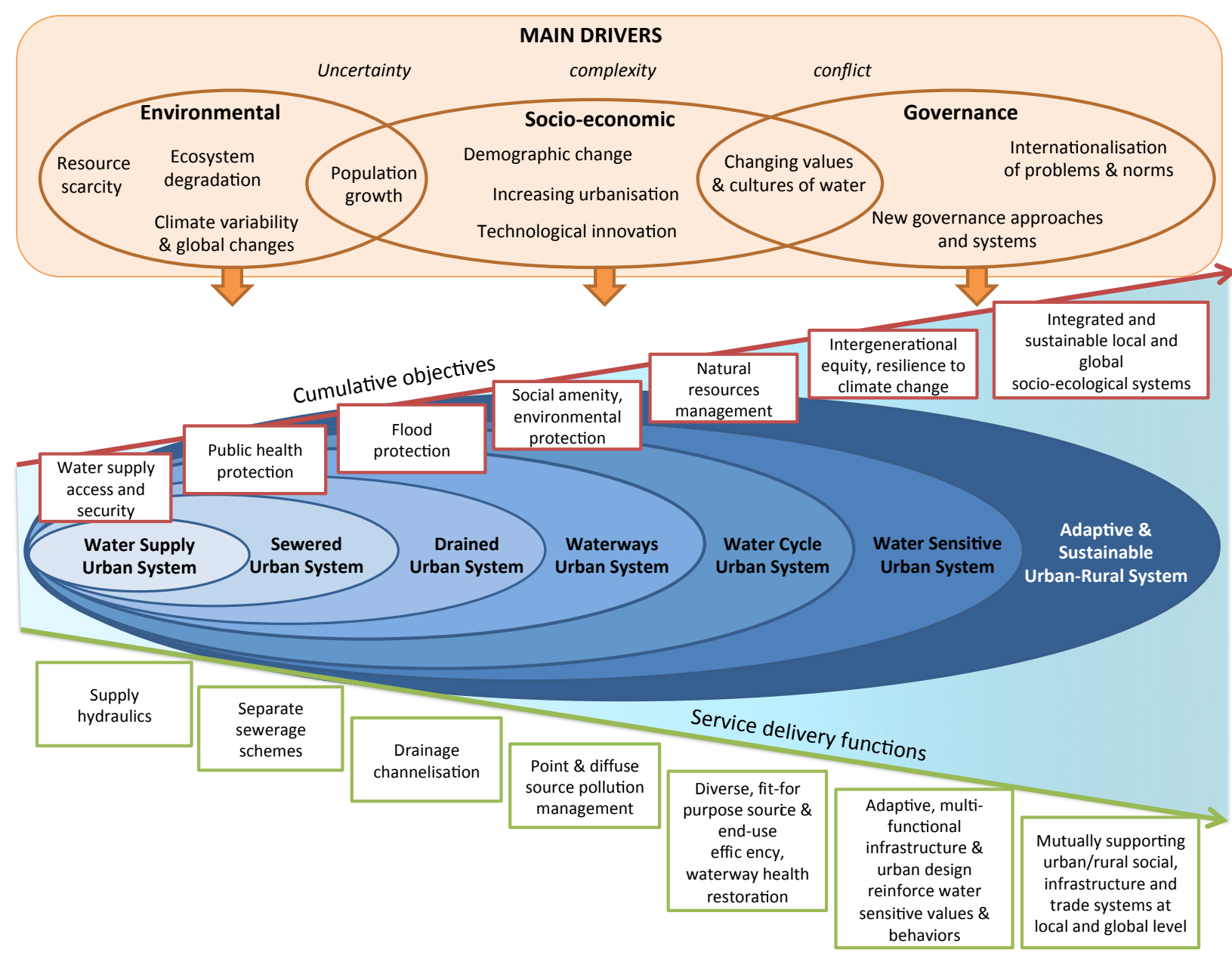

Figure 2: Drivers and resulting evolutions in urban water systems. Adapted and extended from Brown et al. (2009)

From Figure 2, we contend that the process of transitioning urban water systems towards more integrated, adaptive and sustainable configurations is a multi-dimensional process. Different objectives need to be increasingly integrated into urban water system management in order to be able to provide a variety of service delivery functions. The scope and dimensions of urban water systems that need to be considered also expand along with these objectives: from local to regional and regimes; from an intra-generational to inter-generational scale; and from sectoral to trans-disciplinary expertise requirements and approaches. As a result, the 'traditional, technical, linear management' approach that has been successfully applied in many urban water systems around the world and that focuses on urban water services to just be concerned with their local population and environment is now typically found to be insufficient and ineffective to respond to the increasing complexity, uncertainty and conflict that arises in water systems. Shifting paradigms and approaches towards more 'integrated, adaptive, coordinated and participatory' approaches to water management (Farrelly and Brown, 2009; Daniell, 2012), where urban water services consider their role as just one actor in the larger water cycle and concerns at a river basin or larger scale, and strengthening 
institutional capacity and system resilience are considered two of the main keys for more successful transitions in urban water systems (Milman et al., 2008; UN-WATER 2012).

Many urban water systems around the world are undertaking actions to transition towards more sustainable configurations of urban water management, but the pathways may, and indeed should likely, be different with different barriers and hurdles encountered. From Australian experience, reported barriers in transitioning urban water systems to more sustainable configurations are largely socio-institutional rather than technical (Brown and Farrelly, 2009). Transition pathways in other countries or regions may also take place at different rates of change with their own challenges (see examples in Tejada-Guibert and Maksimović, 2001; Jenerette and Larsen, 2006). For instance, the pathways adopted in Tanzania towards sustainable and community-based urban water management and the challenges they face (Cleaver and Toner, 2006) would be different from the pathway adopted by Australia (Mitchell, 2006; Brown and Farrelly, 2011), Sweden (e.g. Hellström et al., 2000), China (e.g. Bai and Imura, 2001) and elsewhere. There is no one-size-fit-all solution to the transition process within or between countries and urban areas.

However, understanding the system change, identifying drivers of change and directions of current and potential transitions could support more strategic decision-making for the adoption of more sustainable and flexible technical infrastructure and adaptive institutions (Pahl-Wostl et al., 2007; Pearson et al., 2010). Using different countries' experience, the purpose of this book is to illuminate and identify the challenges and opportunities that arise through urban water system transition journeys, as well as how these systems can be piloted towards a more resilient and sustainable futures.

To thus support the challenges of understanding and managing urban water in transition, we have developed a multi-authored and multi-disciplinary book that brings together a range of perspectives from various parts of the world. In total, the book comprises 28 chapters written by 51 contributors. These chapters have been grouped into three general sections on:

1. Water supply and sanitation;

2. Water demand and water economics; and

3. Water governance and integrated management.

There is some thematic overlap across the sections due to the inherent inter-connections of these facets of urban water systems. Each section also includes both theoretical, historical and case-study based investigations of transitions in different areas of the world.

Collectively the book is much more than the sum of its parts. It offers innovative insights, practical guidance and best practice insights for managing water in the $21^{\text {st }}$ century.

\section{Drivers of transition in urban water}

In this section, we describe factors (internal and external) linked to those outlined in Figure 2 that have, or will have, an important impact on the functioning of urban water systems in different parts 
of the world. For each of the drivers, we provide a brief description of issues involved and the resultant challenges they present for the effective functioning of current technical, economic or institutional models for urban water management. The general drivers of complexity, uncertainty and conflict are integrated into the descriptions of each of the drivers where most relevant, but interested readers are referred to the discussions on managing wicked or unstructured problems for more specific discussion on these (e.g. Rosenhead and Mingers (2001) for a general overview or Daniell (2012) specific to water management). Section 3 then looks at how transitions in urban water systems are manifesting linked to these drivers.

\subsection{Population growth, demographic change and increasing urbanisation}

Over recent decades, population growth in many countries and migration of rural population to urban centres has resulted in rapid urban demographic growth. In developing (and to a lesser extent in developed) countries, this rapid expansion of cities provides many challenges, including for urban water management, such as how utilities in charge of water, sanitation and storm water management services are managed.

The first challenge confronting water managers is the need to increase water supply in order to meet fast growing water demand. Quenching urban thirst is particularly challenging in emerging economies where the effect of population growth on water use is accentuated by the increase in living standards. Local resources, in particular groundwater, are often overexploited, generating a series of negative impacts including seawater intrusion, the decline of groundwater dependent ecosystems or land subsidence (e.g. Mexico City, Bangkok, Beijing, Jakarta.). As local resources become insufficient to sustain urban development, cities typically seek to tap increasingly distant resources, through the development of dams, canals or piped transfers. This often leads to conflicts with stakeholders of rural territories, who oppose the predatory behaviour of cities that they consider to be grabbing "their" water resources (see Rinaudo, this volume, on inter-basin transfers). Nonconventional resources such as desalination or wastewater recycling can also be used to meet growing demand in the developed world, but their cost remains prohibitive for most cities of emerging economies. Water supply thus remains a major challenge in many parts of the world.

The second challenge is how to ensure that development of sanitation and wastewater treatment infrastructure keeps pace with the galloping demographic growth and urban sprawl. The issue is particularly sensitive in developing countries where largely unplanned, informal or slum settlements host a very large share of the population (see for instance Makaudze and Geddes, this volume, for a South African illustration). What is at stake here is not only comfort and the quality of life but also health, as is illustrated by the Zimbabwean case study of Nhapi, this volume and also by White and Falkland in their Pacific Islands case study. It is also an issue of ecological sustainability as water borne pollution from cities can contaminate large parts of river systems located downstream, groundwater and/or estuary and marine ecosystems, threatening the resource base of rural communities in those areas.

Urbanisation also drastically alters the hydrological cycle. The increase in impervious areas (e.g. rooves, roads, paved areas) reduces infiltration and groundwater recharge, accentuating groundwater 
depletion. It also increases volumes of run-off, flash-flood risk and accelerates the transport of pollutants from urban areas to wastewater systems and downstream rivers and environments. As metropolitan areas grow, the size of the centralised infrastructures required to manage storm water become increasingly costly and space consuming, leading urban water managers to consider the use of small scale decentralised technologies for on-site retention, recharge and natural treatment of polluted stormwater in ponds, constructed wetland or root-zone treatment facilities. The development of these decentralised technologies is increasingly integrated into urban development planning and not only considered as a water management issue (see chapter by Hussey and Kay, this volume). They also intend to promote ecological sustainability, though the production of ecological services (biodiversity, filtration, artificial groundwater recharge), turning stormwater from nuisance into a resource. Urbanisation also alters the hydrological cycle through the increasing importation of "embedded water" in food and materials bought, used and consumed by urban populations. For example, 2002 estimations in Sydney showed that almost half of water consumed by households was embedded in their food compared to just over $10 \%$ that was from the city water supply used for drinking, gardening and other household activities (ABS, 2002).

Financing the development, maintenance and renewal of water supply, sanitation and storm water management of growing cities is another major challenge. As health and environmental standards in many areas of the world become more stringent, the cost of water supply production and waste water treatment increases. In parallel, managers of urban water utilities are increasingly expected (by national regulators or by external donors) to recover investment and recurring costs thought higher user fees and charges. This cost-recovery objective is particularly difficult to achieve in poor countries where users' capacity to pay for water services remains low (e.g. Makaudze and Geddes, this volume). In emerging and developed countries alike, there is also a risk that a non-negligible percentage of the population stops using services, as they cannot to pay for access to them. Higher water fees may also provide incentives for the better-off users to bypass public water systems which they find to expensive, turning towards private supply solutions, such as private bore-well, rainwater harvesting and grey-water recycling systems (Montginoul and Rinaudo, 2011).

This cost recovery imperative thus seems partially in contradiction with the social dimension of sustainability of urban water systems. Population growth is often accompanied by demographic changes such as increased inequality and poverty. A key challenge faced by utilities consists in developing innovative poverty alleviation schemes that ensure fair access to water supply and sanitation without jeopardizing the economic sustainability of the system.

\subsection{Increasing resource scarcity, including water}

The second main driver, after demographic growth, is the increasing scarcity of resources needed to support human activities and lifestyles. Global analyses show that we are rapidly heading towards the limits of easily exploitable or renewable resources, and that this growing exploitation is having serious impacts on many human and ecological communities (e.g. Rockström, 2009). For example, maintaining access to freshwater, clean air, healthy soil, phosphorus, energy and many other chemicals and minerals required for life, including food production (e.g. Lymbery and Oakeshott, 
2014), is an increasing challenge at many local, and sometimes, global scales; presenting significant challenges for urban (and rural) populations.

Looking specifically at water resources, scarcity is currently not an issue when looking at global statistics (e.g. Palaniappan and Gleick, 2009; Rockström, 2009), but is locally often significant due to a mismatch between freshwater and population distribution. This leads at a local and regional level to conflict and need for cooperation over scarce water resources between different users (Delli Priscoli and Wolf, 2009), including urban and rural populations or different states (e.g. California Arizona dispute over Colorado water). This scarcity will be reinforced in the future by climate change and its hydrological consequences, including the potential for reduced reliability of reservoirs and reduced groundwater recharge. Scarcity, at least in the sense perceived by human populations, is also due to strengthening environmental regulations (e.g. the Water Framework Directive in Europe or Endangered Species Act in the USA) which have led to increased environmental water allocations in order to maintain ecosystem health and services, often at the expense of existing diversion infrastructures, which have their capacities reduced.

\subsection{Technological innovation}

Technological innovation is an important driver of change in urban water systems. In the 1980's and 1990's, transformations induced by technological innovation in the urban water sector mainly concerned water utilities, through the development of new treatment technologies. The development of membrane filtration techniques freed urban water managers not only from the water scarcity constraints (e.g. desalination, reuse) but also from environmental constraints (e.g. urban effluent treatment). Recent innovations in that domain include the integration of new treatment technologies into river basin management (spatial and temporal up-scaling) through groundwater replenishment programs (e.g. Orange county in California, Adelaide in South Australia, see also Nelson et al., this volume) or indirect reuse (e.g. Singapore, see Yog et al., this volume). Simultaneously, there is a shift from chemical engineering to ecological engineering with the development of innovative biological treatment technologies which provide a wider range of ecological services including water purification, biodiversity, landscapes and storm water retention (Barraqué, this volume). This innovation seeks greater integration of water and land use planning (see also Section 3.5). The uptake of such innovation is however limited by their costs, which make them unaffordable for many developing countries), by consumer acceptance problems (reuse in particular); and health-related regulatory constraints.

In parallel with large scale technological innovations, the water industry is also developing innovative small scale technologies, targeting individual users (industrial, commercial and domestic water users). From reverse osmosis to grey water recycling, technologies are, and will increasingly become affordable to individual users, who could choose to invest and by-pass collective public water services. Examples abound in Australia, where decentralised storm water management, drinking water treatment and wastewater treatment and recycling systems were promoted by public policies during the Millenium drought. The decentralisation process challenges the current technical and financial organisation of water systems, based on the principal of universal public services (see Barraqué et al, this volume). 
Change in urban water systems is also driven by organisational management innovations in the field of computing, information and communication technologies (ICT) that can be used for monitoring (e.g. sensors, smart meters, smart devices) and automation of increasingly interconnected systems (e.g. water grids). This is expected to lead to increased flexibility of demand and supply in time and space. The development of market instrument innovations (e.g. tradable water rights, option markets, spot pricing), by increasing water reallocation possibilities, will reinforce this evolution. It is thus the combination of technological and institutional innovation that will allow increasing flexibility and theoretically resilience of urban water systems. New ICT tools are also likely to drive changes in the relationship between users of urban water systems and those who operate them. The development of smart phones, home automation technologies and smart meters allow two-way communication between the managers and customers. This opens up new opportunities in terms of short term demand forecasting or use of spot water pricing for instance, such as what is already widely practiced in the energy sector. In the longer term such innovations may allow improve tracking of water provenance/quality testing, and monitoring the risk and signs of potentially disruptive events (e.g. contamination attacks, ruptured or leaking water systems) over the long term.

Clearly, the technological innovations described above offer opportunities for improving the performance of urban water services. Their uptake will however depend on their cost and perceived added-value they provide compared to existing systems, as consumers and local politicians of most developed countries are reluctant to implement changes that significantly increase water bills or citizen discontent over the short term. Innovation uptake will also depend on organisational transformation in the water sector, as discussed in the next section.

\subsection{New water governance approaches and systems}

The technological changes described above are also accompanied by changes in terms of governance of urban water systems. The progressive development of decentralised technologies and infrastructures challenges traditional top-down and technocratic decision-making, requiring more collaboration and harmonisation across fragmented systems. The automation of water systems, from large supply networks to smart metering, also leads to the shifting of power to experts capable of deciphering increasing mountains of data, whether at the large or local scale. In long-term planning, water utility managers now need to take into account the fact that hundreds of individuals or small groups can take independent investment decisions that are possibly inconsistent with their own objectives. They thus need to provide incentives (moral, economic, infrastructural) to influence those decisions in their desired direction. This evolution drastically changes the relationship between urban water managers and users, and necessitates changes in communication strategies between these groups. Managers have to meet a growing demand for transparency and for effectively involving citizen, communities and other private actors in the regulation of water utilities. In practice, consumer participation ranges from common sense customer care (one-way process) to cooperative ownership and management. Intermediate forms of participation include structured consultation procedures (such as public hearing, often mandated by law) and the participation to advisory committees or regulatory boards (Muller et al., 2008). This demand for transparency and participation by a range of stakeholders is particularly strong concerning the issue of public-private partnerships (PPPs), as private sector participation can be contested by citizens, consumer and 
environmental associations and even by some elected politicians. However, there remains a significant gap between the recognition of participation as a citizenship right, as outlined in legal frameworks like the Aarhus Convention (UNECE, 1998) and the actual practices to allow citizens expressing their preferences and grievances. Bridging this gap is one of the main challenges urban water utilities will have to take-up in the coming years.

Another major governance change is the progressive integration of urban water systems with urban land use planning (vertical integration) and river basin management planning (horizontal integration). Vertical integration takes place through technical, legal and economic cross-linkages between land use, water supply, sanitation and storm water planning documents. Horizontal integration requires urban water planners considering broader environmental objectives at river basin level. Put differently, river basin level environmental constraints "enter the city" and simultaneously, the city is increasingly accountable for its impact outside its direct control area. A consequence is that urban water managers need to construct new coalitions with stakeholders with whom they did not previously have to interact.

\subsection{Changing water values and cultures}

Water is valued in many different ways by people. As a vital and non-substitutionable element of life for both humans and the environments they depend upon, people often have both spiritual and emotional attachments to water, as well as relationships to it for specific needs (e.g. drinking, washing, growing food, recreation). As economic wealth and living standards of urban populations increase, water service beneficiaries' mindsets often shift, as can the relative importance of some of these different values and cultural relationships to water. This can drive changes in values and cultures, for example from that of users to customers who, paying non-negligible fees for water access and use, have growing expectations in terms of quality of the service and their rights, and those of the urban administration to use water for purposes they consider important (e.g. maintaining green lawns, washing cars or filling swimming pools). Customers of urban water systems typically expect greater reliability of supply, intermittent supply being perceived as an unbearable infringement on domestic comfort for which they pay. They also expect water quality (bacteriological and chemical) to improve as their sensitivity to health risks progressively rises. Meeting this new demand is a major challenge for utilities, as they may not have the technical capacities to improve the performance of the technical systems they operate. Public utilities may also lack the financial means to carry out the required investments, partly because only a fraction of the customer base has the required capacity to pay for improved services.

The increasing use of water pricing as a tool to recover cost or to promote efficient water use has also resulted into a growing opposition to the commodification of water, with a growing demand from some social groups to treat water supply and sanitation as a basic right which should be freely accessible to all. Reconciling economic efficiency, cost recovery and equity is a major challenge which some utilities attempt to address social water rates while other prefer to treat equity outside the bill through traditional social programs. 
Last but not least, many urban citizens are increasingly aware of the environmental impacts of urban water services and sensitive to the aesthetic and recreational values of water in the city. Particularly in developed countries, this results in a growing demand for low environmental impact technologies (storm and wastewater treatment) and in some cases for scenic urban river ecosystems, which contrast with the strict and rigid urban environment. Water planners thus need to reconsider the design of infrastructure which no longer needs to be made invisible but which can become a constructive part of the urban landscape (e.g. replacing underground stormwater storage with ponds and wetlands, and making river banks accessible for pedestrians) and valued for both its aesthetics and utility by residents.

\subsection{Climate variability and global changes}

Climate variability and other global changes, including climate change, are significant drivers of urban water management decisions. For example, urban water sector managers frequently need to make decisions concerning long-lived investments, considering expected long term trends (and uncertainties) in terms of climate variability (e.g. lengths of likely dry/wet periods, and level and frequency of extreme hydrological events), demography, urban development, water demand, energy prices, technology and climate.

Climate change is a key driver of change, expected to have far reaching consequences for urban water systems. Changes in temperature and rainfall patterns will affect available water resources (rivers and groundwater) in particular during low flow periods; the quality of surface water resources (loads of contaminants and suspended solids); flood risks and inundation patterns; and the state of water dependent ecosystems in general (Whitehead et al., 2009). Most urban water infrastructure will need to be adapted (capacity expansion), or operated differently, to cope with the new weather and hydrological conditions, including the reservoirs; inter-basin transfer schemes; wastewater treatment systems; storm water management schemes and other water infrastructure (e.g. desalination and water recycling plants; rainwater tanks). In coastal areas, urban systems will further be impacted by sea level rise which will threaten systems in different ways, including: local water resources (e.g. sea water intrusion in coastal aquifers), low-lying supply and sanitation infrastructure; and flood protection infrastructure. The challenges of climate change are not only technical, but economic, as the required adaptation will impact the cost of urban water services, which is already increasing in response to other changes described in the previous paragraphs.

A major concern of urban planners and water managers is that the uncertainty attached to future climate predictions is significant. This uncertainty is not likely to disappear as knowledge and climate models improve, implying that decision makers need to learn to live better with it. A consequence is that new infrastructure should be designed considering that it will need to cope with a larger range of climatic conditions than in previous centuries and that this range will remain highly uncertain (Hallegate, 2009). This calls for new approaches aiming at either identifying the most robust solutions (Graveline et al., 2014) defined as the most insensitive to climate conditions, or very flexible approaches that can be adjusted with changing conditions (Gordon, 2013; Daniell, 2013). Adopting such robust and/or flexible decision making methods represents a shift in paradigm for water practitioners whose actions have long been driven by the search for optimal solutions but their 
use is already emerging in the water sector (Groves et al., 2008; Daniell, 2013). The difficulties associated with the design of such flexible strategies are illustrated with the case of Melbourne, Australia (Grant et al., 2013).

Climate is not the sole source of uncertainty that confronts urban water planners and managers. Population and economic growth, technology, water demand, energy prices and prevailing political conditions are also unpredictable variables, many of which are discussed in other parts of this section on drivers. In this new context, the use of contrasted scenarios is increasingly used to identify robust solutions (Graveline et al., 2014). Optimisation is progressively replaced with different practical decision making strategies. Hallegate (2009) distinguished five such strategies. The first strategy consists in choosing "no regret" options which positive outcome over a wide range of future developments. The second is the "reversible strategy" which aims to keep the cost of making the wrong decision as low as possible, for instance by developing water infrastructures which can be upgraded at relatively low cost, or removed and relocated as sea-levels rise (Gordon, 2013). The third is the "safety margin strategy", which consists of calibrating new infrastructure assuming upperbound estimates for some of the assumptions made, so that the solution implemented is able to cope with almost every possible future development (within current imagination); this solution is only feasible when the marginal cost of oversizing infrastructure is small compared to its total cost. The fourth strategy consists of developing institutional frameworks that promote flexibility and adaptation of individual agents to changing conditions, the "soft strategy" or "soft path" (Wolff and Gleick, 2002). This includes long term planning strategies such as those included in water resource management plans in the UK or California, which impose thinking several decades ahead (see also Rinaudo, this volume, on long run water demand forecasting). The use of economic instruments such as water markets, option contracts and insurance are also illustrative of this strategy. They imply much less inertia, reduced risk of sunk costs in case of wrong decisions, than with hard adaptation strategies relying on infrastructure. The fifth and last strategy consists of reducing decision making time horizons, acknowledging that uncertainty increases rapidly with time. This implies opting for technical solutions that have a shorter lifespan.

\subsection{Ecosystem degradation}

Ecosystem degradation is another significant driver of the need for transformation in urban water systems. Decades of urbanisation and economic development have tremendously increased the pressures on water resources and dependent ecosystems, including long term contamination, water resources depletion and loss of habitats and biodiversity in urban areas and their connected regions. The loss of ecosystem functions (e.g. water filtration/purification; seasonal flow regulation; erosion and sediment control; and habitat preservation) has led to new costs to urban areas, as damaged natural assets have had to be replaced with artificial infrastructure such as wastewater treatment plants or storm water retention infrastructure. Despite growing social concerns and movements over environmental matters and halting degradation since at least the 1970s, there is now a growing awareness that more effort should be dedicated to protecting river ecosystems within urban areas (rather than just those in "pristine" wilderness areas), to rebuilding and conserving remaining urban biodiversity (especially in the peri-urban fringe and along water corridors) and to managing pollution and increasing toxicity of the urban and linked rural environments. Designing institutional 
mechanisms which encourage higher levels of protection of watershed hydrological services is thus one of the main challenges urban water managers will have to address in the coming decades, both in developed and developing countries.

\subsection{Political ideology and development of international norms}

Political ideologies, linked to different values related to water discussed in Section 2.5, drive the development of different kinds of urban water systems, water policies and their governance structures. Ideological motivations have a great influence on policy choices, in particular concerning what services should be provided to the "public", and how these are financed, implemented and regulated. In urban water there are a few different political ideologies vying for attention and translation into the development of specific forms of urban water infrastructure, policy instruments and governance structures. In much of the world, there is a strong political ideology that water, including in urban areas, is and should be treated as a public good, leading to policies and international statements enshrining the "Human right to water" into law (Republic of South Africa, 1998; United Nations, 2010).

Since the early 1990's, the recognition of the economic value of water (e.g. ICWE, 1992) also laid the foundation for a neoliberal political ideology and model of water policy based on market centred governance of water resources and services. In the water and sanitation sector, private sector participation (PSP) was pushed by many national and international agencies and water associations, including the World Bank, IMF and World Water Council, based on the assumption that private institutions are intrinsically superior to public institutions for the delivery of goods and services. The development of this ideology, which still underlies current policies in many parts of the world, resulted in the emergence of multinational private monopolies in developed and developing countries. Despite this ideology dominating thinking in many urban centres, there is a growing recognition that the expected outputs of PSP in terms of efficiency gains and extension of coverage towards the poorest social groups have not materialized. Some authors even suggest that "policies based on a commodification of water and sanitation services are intimately related to the increasing inequality that has been recorded in developing countries since the 1990s" (Castro, 2007). PSP has also been increasingly contested by citizens and politicians, as such evidence has highlighted the weakness of States to exercise regulatory control over private operators, particularly in weak democracies (Castro, 2007; Ohemeng and Grant, 2011). The ideological movement aiming at reversing private sector involvement in water services delivery to citizens, born in Latin America is now gaining momentum in Europe and increasingly becoming an important local political issue (Barraque, 2012).

A third significant political ideology that attempts to drive urban water reforms but has not yet gained sufficient power to force widespread policy changes is the green or ecologically rooted ideology that recognises that there are limits to growth and use of resources on the planet (see also Section 2.7). Much of the environmental engineering paradigm (see Barraqué, this volume) and concepts like "water sensitive urban design" stem from this ideology. Such an ideology also underlines the need for a reworking of the neo-liberal economic system and power structures to decouple economic growth from resource use, leading to it to support businesses based on renewable resources or environmental protection. The more moderate subscribing to such an ideology might 
also support economic instruments such as payments for ecological services, for example to protect drinking water catchments and reducing the need for chemical treatment and the energy costs associated with it. The final ideology that is gaining some ground and driving change, but still relatively marginal in urban water, is that of deliberative democracy and the rights of all people to participate in decision-making processes that affect them. Such an ideology is evident in documents such as the Dublin Statement (ICWE, 1992) or the Aarhus Convention (UNECE, 1998) and has been translated into other policy documents like the European Union's Water Framework Directive (EU, 2000; see also EU, 2002) or South Africa's national water policy (Republic of South Africa, 1998).

\section{Adaptations and transformations in urban water systems}

Following on from the drivers of change in urban water systems and the challenges that these lead to, this section describes the resultant changes, adaptations and transformations that are taking place in urban water systems. Here we describe these changes or directions of potential transition in terms of the desired movement in the urban water system. Many of these relate to the objectives in Figure 2. We also outline how the contributions of this book relate to these transitions or need for system movement in that direction.

\subsection{Improvements in public health and equality of service}

Health impacts resulting from a lack of easy access to potable water and sanitation of an acceptable quality are still significant in many places around the world. There are large inequities both between and within different countries on who is able to access water services of an acceptable quality, which is why one of the most significant transitions in urban (and rural) water systems sought on a global level is for improvements in public health and equality of service. Such objectives have previously resulted in transitions to centralised water supply and sewerage systems, piped into individual homes, as discussed for example by Troy (2008) and Bichai and Smeets (this volume). As Bichai and Smeets outline, this is specifically as it has been easier to manage water quality systems in centralised, rather than decentralised systems, due to the ease of implementation of monitoring and treatment regimes. However, in response to other drivers such as increasing resource scarcity and alternative water governance systems and approaches, strains can appear in centralised systems in both developed and developing countries for different reasons. As Nhapi (this volume) outlines, well performing water and sanitation system can rapidly cease to perform their key functions if the conditions for their effective management is not maintained. This was the case following a major economic and political crisis, where a water and sanitation system in Zimbabwe fell quickly into disrepair leading to a major cholera outbreak. In some developed countries, water security issues due to climate variability, change and potential reductions in water availability from traditional sources (e.g. dams, inter-basin transfers) in some regions, including Australia and Singapore have prompted suggestions for and implementation of recycled greywater and sewerage to be reinjected into potable water supply systems (see Kog, this volume on the Singapore case). This has led to concerns from some researchers and the public over the heightening of health risks (e.g. due to potential contaminents such as endochrine disrupting chemicals that are difficult for treatment systems to 
remove) in these centralised systems and led to the investigation of alternative decentralised and centralised water management options including "fit-for-purpose" use of different water sources, which may carry their own health risks, as outlined by Bichai and Smeets (this volume), Rinaudo et al. (this volume) when investigating use of bore water, and Garcia-Valinas and Reynaud (this volume) who demonstrate how households react to information on water quality by changing their consumption habits. Despite the potential issues that can develop around alternative systems and behaviours, Nelson (this volume) discuss how systems of governance and regulation can be put in place to ensure adequate water quality across both urban surface and groundwater services, providing an example in California, USA.

Adoption of alternative water systems in the community can also lead to inequities in the quality and quantity of water accessible for use occurring in these affected areas. Inequity in access to water and sanitation is obviously also a major challenge in much of the developing world with many millions lacking these basic rights, as outlined in our introduction. Makaudze and Gelles (this volume) speaking about working towards rectifying this situation in South Africa and Nhapi (this volume) on Zimbabwe, provide some insight into the challenges of service provision to all in the community, particularly some of the poorest urban residents living in slums. White and Falkland (this volume) also provide some insights into the challenges in the Pacific Islands where traditional governance systems are challenged by increasing urbanisation. For areas that do have functioning centralised systems, there are ways of designing water tariffs in a way to ensure access to the poorest is possible, as outlined by Nuages et al. (this volume) related to Eygpt and Chan (this volume), related to many systems around the world, including the specifics of what occurs in Australian tariffs in order to integrate social and environmental goals, and responsibility for them, into the urban water sector.

\subsection{Protection of life, livelihoods and ensuring well-being (of humans and the environment)}

A number of the drivers and the changes and challenges they induce in water systems have an impact on people's lives, their livelihoods, their health and wellbeing and that of the environment. These have led to transitions in the urban water systems to protect and reduce the risk of loss of life, for example due to a lack of access to adequate water and sanitation, as outlined in the last section, or through special provisions for flood and drought management. For example, Van Vliet and Aerts (this volume) highlight how initial modifications in urban environments at risk of riverine, estuarine or coastal flooding were made to protect populations from recurrent events through hydro-technic infrastructure like dams, dykes and levees. They show how we are seeing a transition past this paradigm of "build and protect" to one where it is important to acknowledge the importance of nonstructural, adaptive measures such as "dry-proofing" (in the case of Rotterdam in the Netherlands) to reduce flood risk. Other authors (e.g. Hallegatte, 2009; Wenger et al., 2013) acknowledge the need to leave room for floodwater and to reduce the risks associated with the failure of flood-defence infrastructure in more extreme climate events through the implementation of a range of both structural and non-structural measures (Daniell, 2013). For urban areas built on deltas, these areas are also often rich agricultural lands that can benefit from the water and sediments transported by floods if adequate compensation and insurance systems for crop and other material losses can be developed for land-owners who make their land accessible for "purposeful" flooding. This kind of 
transition to developing more non-structural measures to support urban water cycle management is also a result of social and environmental drivers outlined in the previous section, including amenity, access to, and quality of riverine environments for well-being. In some cases, as demonstrated by the case of the St Charles River in Quebec, Canada (Brun, this volume), this has actually led to the removal of water infrastructure and "renaturation" of rivers in urban environments.

\subsection{Encouraging resource efficiency or 'doing more with less'}

Environmental and social imperatives, as well as economic ones have also led to a transition in urban water systems in terms of seeking high levels of resource efficiency and "doing more with less" rather than just staying in the paradigm of increasing supply to match demand. This evolution is sometimes supported by regulations imposing water use efficiency thresholds. The evolution towards a more resource efficient society challenges the prevailing culture of water experts and consumers alike, who tend to consider water resources as unlimited and demand as uncompressible. The objectives in these new systems are to attempt to develop means of reducing water consumption, demand and waste (Guy et al., 2001), as well as ultimately to decouple economic growth from resource use (water, energy and other materials, minerals and chemicals) (e.g. Hargroves and Smith, 2004; see also Kenway and Lant, this volume, and Hussey et al., 2013).

In order to effectively transition to such systems, Troy (this volume) highlights how more significant changes than the water education and efficiency programs currently implemented (e.g. low-flow shower-heads, dual-flush toilets and water-efficent dishwashers and washing machinge) will be needed for larger gains. These alternatives could include using potable supplies for only kitchen and bathroom uses then using treated wastewater or sewage for laundry and outside (e.g. garden) uses and installing dry-composting toilets. The role of water metering and pricing mechanisms is also acknowledged by Troy (this volume) and Garcia-Valinas et al. (this volume) in inciting behavioural change that is required support a successful transition in this direction. Other issues of waste reduction are also important, adding considerably to urban water use and costs. For example, Dimova et al. (this volume) looks at how better management of extraneous water can lead to better economic and environmental outcomes. There is widespread and growing interest in promoting conservation in the industrial and commercial sectors. As Renzetti (this volume) outlines, governments in different countries are developing water conservation plans and manuals for firms seeking to reduce water use (e.g. target setting and benchmarking, and providing subsidies for water efficiency measure in of small and medium-sized firms). Other governance mechanisms can also be implemented to seek efficiencies in water management systems such as separation of water service functions (e.g. water and sewerage) or installing independent economic regulators with water services oversight (Reinhart and Guerin-Schneider, this volume).

\subsection{Commodification and economic valuation of water}

Linked to the important transition to conserving and using water more efficiently, and to improvements in health and equality of service is the increasingly widespread transition to the commodification and the economic valuation of water (see also Section 2.8 on the political driver behind this transition). With the acknowledgement of social and environmental values for water, and the limits to water access for many in urban systems from their own locally available sources (e.g. 
rooftop, well/bore, local river or lake) comes the possibility and often need to monetarise the purchase of water. Additional factors that lead to a transition in urban water systems to different economic valuations of water are: the need to recover costs of water supply and sanitation infrastructure development and maintenance; to manage demand; to increase profits for public or private stakeholders; or to create water transfer and trading systems. Although a few urban areas around the world still provide water for no cost to residents (see Chan, this volume, for details), many urban residents have to pay for water, either from local water authorities, or legal or illegal vendors, as occurs often in slums or some other disadvantaged urban districts. Often these water charges, typically paid by the poorest, are much more exorbitant per litre than what richer residents would pay for a much better service (see Swygendouw, 2004, for a discussion of these issues in Bolivia). However, in many areas where there is a culture of free access to water (which is typical in many rural areas around the world), and water services are provided to urban residents through government or donor-financed programs, water authorities can struggle to enforce payment of water bills and hence face difficult challenges for cost recovery of the services (see for example Makaudze and Gelles, this volume, on the challenge of implementing this transition, desired by some but not by others, in the South African context).

Economic valuation and tariff setting of water typically varies on a number of factors, as Chan, this volume, outlines, including the water pricing: principles and objectives; processes and tariff structures; and desired outcomes, linked to other policies. They may for example not be relatively static like different types of block tariffs, but be more flexible and dynamic, like for example spot pricing, seasonal water rates or scarcity pricing (Grafton and Ward, 2010) or those that reflect the cost of current consumption and opportunity costs of future supply (Sibly and Tooth, this volume). Their use is facilitated by the spread of technological innovation. For instance, smart meters allow consumers to better understand and monitor their own consumption and adapt their practices to respond to changes in tariffs. More flexible pricing systems, like those that represent the prevailing market value in a region, as in some trading systems, also present opportunities and challenges under this new paradigm. For example, Nelson et al., this volume, show how innovative legal frameworks can help to overcome difficulties in rural-urban water trading and encourage more efficient use of scarce water resources. Although some consider that there are potentially ecological and social externalities created by a re-engineering of the water cycle through trading and the physical infrastructure that allows it between typically non-hydrologically communicating systems, this transition pathway is starting to accelerate in many places, including those where it may not have been expected, like in China (see Squires et al. (2014) for greater discussion on these challenges and the resulting transitions).

A side effect of this transition to commodification is that it increases the cost of water services for large users or residents may decide to develop their own water supply or sanitation systems. While the development of independent water supply systems remains a limited phenomenon, it could threaten the long term technical and financial sustainability of public water services in the future. The main question is how to cover fixed costs when the customer base erodes? 


\subsection{Low impact development or "water sensitive urban design"}

In order to enhance environmental and aesthetic outcomes in urban settings, and to overcome many of the challenges highlighted in Section 2, there is a strong push by a number of water academics and stakeholder groups to transition urban water systems to forms of lower impact development or "water sensitive urban design" through use of more ecosystem-based approaches and technologies such as wetlands and renaturation of rivers, coupled with decentralised collection, treatment and fitfor purpose reuse strategies (e.g. NWC 2011; Hussey \& Kay, this volume; Brun, this volume). The "Water Sensitive Cities" Cooperative Research Centre in Australia ${ }^{1}$, are seeking to champion these concepts, as are other groups within governments in a less direct manner, like the Office of Living Victoria in Australia with its new Melbourne water strategy based on Integrated Water Cycle Management analyses and the resultant mix of centralised and decentralised systems that are intended to increase urban system sustainability and water use effectiveness and efficiency (Coombes, 2012; OLV, 2013; see also Reinhart and Guerin-Schneider, this volume, on the context of these reforms). Although there are increasing numbers of relatively small-scale projects, showing the potential for a transition to these forms of water cycle management, in most cases, generalised uptake of these kinds of systems are only in pre-development or just starting to "take-off" (Figure 1). Further implementation faces a range of challenges and political struggles as outlined by Keath and Brown, 2009; Brown et al, 2011; Daniell et al., 2011; and Hussey and Kay, this volume.

\subsection{Integrated or whole of systems approaches}

An extension of the "water sensitive urban design" concept discussed in the last section, a transition to integrated or whole of systems approaches implies that all resources and issues within a specific boundary will be treated managed holistically towards having the most sustainable and self-sufficient system possible. The kinds of urban resources, stocks and flows considered in these approaches cross multiple boundaries and include water/energy/materials/food/waste/land/social/economic nexus issues which are all vital to the sustainability of urban systems (Sheehan, 2007). One concept that represents this kind of urban systems approach is the "urban metabolism" that looks at inputs and outputs to cities and the quantities of "embodied resources" used in the development of other resources: for example, the quantity of energy used in Water production (Kenway and Lant, this volume) or water used in energy production (Hussey et al., 2013). There are also a range of other "integrated" approaches that seek to address issues previously siloed in urban water management collectively, such as surface water and groundwater (Nelson et al., this volume) or seeking to make multi- rather than single- objective evaluations, for example of economic, social and environmental costs and benefits to urban water system infrastructure renewals and development (see Marlow et al., this volume). Transitions to some of these integrated approaches are becoming more widespread in the urban water industry (see Barraque, this volume on the growing paradigm shift to "environmental engineering" from previous "civil engineering" and "sanitary engineering" approaches, but there is still typically more work required to achieve more seamless integration of urban resource management, planning and maintenance systems that are required for the effective understanding and implementation of whole of systems approaches.

\footnotetext{
${ }^{1}$ http://watersensitivecities.org.au
} 


\subsection{Resilient and adaptive systems}

Moving from the structure and content of the urban system and its management, to its ability to respond to a range of drivers in Section 2, the next transition of urban water management systems we consider is one to more resilient and adaptive systems. Previous urban water paradigms have focussed on the robustness and reliability of urban water systems to respond to population demands and climate extremes. However, there is increasing recognition that the robustness of systems may actually lead to more catastrophic failures if the system design parameters are exceeded by extreme events. A transition to therefore developing more resilient systems that able to bounce back from extreme events and more effectively adapt to changes in urban and their linked rural and global systems is sought in many urban water management systems around the world. This can hopfully occur by ensuring a requisite variety of water systems and capacity to respond effectively under such pressures as population and political changes, floods, droughts, storms, sea level rise, pollution, contamination, or disease outbreaks, or other significant events such as climate step changes, dam breaks, earthquakes, tsunamis, electricity failures, or fires (e.g. Daniell 2013; van Vliet \& Aerts, this volume). There are many tools that are available to support the acceleration of this transition (Figure 1). These include: improving long-term water demand forecasting modelling (see Rinaudo, this volume) and understanding the determinants of not only residential but industrial, commercial and institutional water demands (Renzetti, this volume); understanding how price and other noneconomic factors influence water users' behaviours, including their choice of uptake or installation of their own "water security" measures (e.g. bores, rainwater tanks) to ensure their own resilience to extreme events and changes in the urban water landscape (Troy, this volume; Garcia-Valinas, this volume, Rinaudo et al., this volume); the adoption of pricing mechanisms for water that are themselves more adaptive to prevailing conditions (e.g. Sibley and Tooth, this volume; Grafton and Ward, 2010, previously discussed in Section 3.4); and by encouraging increased hybridisation and potentially redundancy in urban water systems that leave them potentially less vulnerable and more resilient and adaptive to a range of foreseen and unforeseen events (see also Section 3.9 and Hashimoto, 1982).

\subsection{Participatory democracy}

Another important transition that is taking off in urban water systems is one to a more stakeholderinclusive and participatory democracy approach to decision-making related to urban water and planning for its future (see also Section 2.8 on the political ideology underlying this transition). This transition is manifested through the integration of a wide range of stakeholders in decision-making and engagement processes around water management, typically for reasons of equity, empowerment, developing shared understandings of values, cultures and problems in order to have a platform for the development of more broadly accepted and legitimated urban water decisions, which will suffer less opposition to implementation and (e.g. Creighton 2005; Dryzek 1990, 2010; Daniell 2012). Participation can take place in a variety levels, from lower levels of interaction in simple information provision and consultation (seeking feedback on proposals/policies/plans), to more interactive and engaged joint analysis and decision-making, or even citizen-controlled decision-making, as in the case of some community collectives or individuals managing decentralised urban water systems. Participation initiatives and stakeholder inclusive approaches to urban water management can also involve just individual or a variety of urban water issues in the same process. Single issue examples 
include initiatives such as citizen's juries or consensus conferences like the Australian Weather Channel's televised citizen jury in 2006 (which also enabled viewers to vote via mobile phone text message) on whether Sydney should build a desalination plant or not, the French consensus conference in 2003 on what should be done with wastewater treatment sludge, and the public debate in Paris, France, in 2009 on the future of their double pipe water network system (Bedu, 2010). Examples of processes that have a wider remit, such as most participatory planning or more creative empowerment and education initiatives, include "re-imagining" urban or degraded rivers through field visits and creative writing in South Yorkshire, UK (Selman et al., 2010), understanding the role of water and why it is valued in urban residents' lives through participatory photography in Nantes, France (Bedu, 2010) and multi-level stakeholder processes for developing strategies to better cope with flood and drought risks in Sofia in Bulgaria, or estuarine and lagoon planning in the Lower Hawkesbury (northern Sydney, Australia) and the Thau Basin (next to Sète in France) (Daniell, 2012; Plant et al., 2014). Even if such processes are not yet really widespread, the increased sensitivity and awareness of urban populations in many parts of the world to environmental and social issues related to water (water pollution, scarcity issues, cost of living pressures) in the population puts additional pressure on water utility managers and governments to disclose information on water quality, as well as on industrial users to protect water sources, to reduce pollution discharge into the water bodies, and to increase water recycling/recirculation. The issue of increasing household awareness and sensitivity to such issues is discussed in Garcia-Valinas and Reynaud (this volume) and Reinhart and Guerin-Schneider (this volume) and social pressure on industrial firms is discussed in Renzetti (this volume). In many cases, social opposition to particular urban water decisions, such as the planned building of new dams, or of inter-basin transfers (see Rinaudo, this volume) can ultimately lead to a reversal of these decisions unless views of the large majority can be changed. For smaller disputes such as between customers of water authorities and these authorities, sometimes formal and informal mechanisms can be put in place to manage and/or resolve these in an orderly fashion such as customer service obligations (CSO), consumer advocacy groups or Ombudsman agencies, like the Independent Energy and Water Ombudsman in Australia. In some places around the world public participation in all water management, including in urban areas is mandated, as for example through the European Union's Water Framework Directive and the Aarhus Convention, yet exactly what this implies and its implementation in reality is far from widespread in many urban water decision-making processes.

\subsection{Decentralisation, diversification and hybridisation of water systems}

One of the most important transitions in urban water management, visible in recent decades, is the diversification and hybridisation of water management systems. As shown in this book, combinations of decentralised and centralised systems are increasingly being adopted, as well as a range of public/private and even community-sector financed, managed, and operated systems. These aspects are discussed by a number of our authors (Reynaud; Reinhart and Guerin-Schneider; Hussey and Kay; Barraqué). This transition to a diversified or hybrid system (from a largely centralised, or largely decentralised, system) has developed in relationship to a range of competing objectives, including enhancing water security through the development of system robustness or resilience. This diversity reflects the innate tensions in the different societal values that underline constructions of 
sustainability (e.g. efficiency, equity, ecosystem and population health, participation, prosperity) and their relationships to urban water management systems.

Issues of water supply security due to climate variability and change, can also lead to a diversification of centralised systems from for example rain-fed dam water to both centralised nonrain-dependent systems like desalination and waste-water reuse and decentralised options where households and districts develop additional water systems to self-provide additional security (e.g. rain-water tanks, groundwater bores, local greywater recycling and sewer water mining and treatment). Likewise, diversification is seen in waste and storm-water systems to deal with changing environmental, social and economic conditions. Water-sensitive urban design pilot programs now sit nestled alongside centralised systems, and there are increasing efforts to "renaturalise" water ways for aesthetic and flood attenuation reasons (e.g. Hussey and Kay, this volume, Brun, this volume), as to septic tanks and ecological treatment systems in some urban areas.

Changing governance systems, from purely publicly or locally operated water systems to the increasing participation of the private sector in water services and infrastructure provision, maintenance and governance has also led to the hybridization and diversification of water systems, through for example public-private partnerships (PPPs) (see Reynaud, this volume), or residents having the choice to either self-manage water, have it supplied buy either public utilities or private vendors, as is becoming increasingly possible in both developed and developing countries, as the sales in bottled water from global companies or local (sometimes illegal) vendors demonstrates (Gleick, 2005; Swyngedouw, 2004). Such hybrid models are not always easy to manage or provide equitable or sustainable outcomes for users of the system. For example on PPPs, there are many different models with alternative allocations of risks and responsibilities under different arrangements. Although many in the water sector had hoped that PPPs would lead to efficiency gains, there is little empirical evidence that PPPs have so far managed to significantly improve technical efficiency, cost efficiency or reduce water prices. However, as these systems now play an important role in many of the world's urban water systems, concentrating on improving governance, accountability, transparency in the contractual arrangements will be important for achieving more long term sustainable outcomes (Reynaud, this volume chapter, Reinhardt and Guerin-Schneider, this volume). Increasing citizen interest in water matters is also leading to the decentralisation (or perhaps more correctly localisation) of issues and the development of "fit-for-community" urban water systems and programs, as discussed in 3.8 .

Other hybrid systems are developing in response to managing competing political ideologies (Section 2.8). For example, private sector participation in urban water systems can be accompanied by strong regulatory bodies to regulate prices and environmental impacts, to guarantee yardstick competition and to allow public pressure through citizen advisory groups. The British solution embodied by OFWAT is maybe a good illustration of this "middle strategy". Alternatives to State or market models are also likely to emerge, involving greater cooperation driven by voluntary association and more decentralised organisation. Hybrid models are also likely to emerge, with private, public and community actors being simultaneously involved in various forms of water supply services and possibly competing for clients. The delivery of water services is not a simple choice between private or public, distributed governance and hybrid forms of organisations will need to be invented. 
Developing such alternative models will require radical changes in the way national and international policy makers approach this matter. This will only happen if the level of effort and political commitment are substantial enough to counter balance the inertial forces set in motion by the neoliberal model and/or government operated monopolies that currently share most of the power in urban water around the world.

\section{Perspectives: challenges and future uncertainties for urban water systems in transition}

The two previous sections have shown that the transformation processes in which most urban water systems are engaged are characterised by great uncertainty concerning the final outcome. Given this uncertainty, we consider there is no point in trying to predict future evolution and identify the corresponding optimal strategy. However, it might be useful for water managers and policy makers to explore possible future evolutions using a limited number of contrasted scenarios, used as tools "to illuminate the choices of the present in the light of possible futures" (Godet and Roubelat, 1996). We would like to end this chapter by presenting two tales of possible evolutions of urban water systems at the 2050 time horizon, as an invitation to participate in foresighting and discussions about current trends and planning for desirable futures.

\subsection{Scenario 1 in 2050: The Engaged State Monopoly}

This scenario relates a story in which the urban water management model based on large-scale technologies and centralised organisational set-up has remained or become the dominant model, in developed, as well as in developing countries. Water services, which back in the 2000s had been established at municipal or a group of municipal governments level, have now merged (both technically and institutionally) and given birth to large regional organizations centred on large metropolitan areas. They are generally publically owned, although sometimes work in collaboration with private and community organisations to provide specialised services including community farms. These new organisations have been able to raise the large funds required to maintain the large and ageing systems (pipe renewal), to increase population coverage (in particular in developing countries) and to deploy new production, treatment and management technologies (developed countries). Following intense political lobbying in 2025, supported by citizen movements for equality of service, a coalition of these organisations and national governments behind them managed to have the "cost-recovery" economic principle abandoned in international policies, with the additional cost of water services being transferred back to normal taxation. With this change, many governments also made changes to legislation to ensure that the state, rather than individual residents, maintained the rights to water that fell on their property, so that they could be assured of sufficient resources for the centralised water collection and treatment systems. To operate increasingly complex and automated systems - from the macro infrastructure system to the micro-household level, which often includes fit-for-purpose pipes for water and nutrient streams (urine and sometimes "thick sewerage" - a combination of diluted and pulverised faeces and kitchen waste) — they employ highly specialized technical staff, as well as significant numbers of community liaison staff. From an economic perspective, economies of scale associated with the use of technologies such as large-scale wastewater 
reuse, desalination, groundwater banking, nutrient recycling facilities and urban flood attenuation parks and wetlands have proven relatively efficient, including for system maintenance costs. Technological advances such as self-monitoring pipes and pipe robots that allow leaks or deposition build-up to be automatically detected and fixed or cleaned have also supported effective network management and renewals. From a risk management perspective, the mutualisation of resources (regional grids) and urban-rural water trading has provided greater flexibility to cope with unexpected developments (drought, major pollution of water resources, drastic changes in water demands). However, the 2027 global coordinated hacker and terrorists' attack (water network contaminations) on some of the world's richest cities' water systems, resulting in thousands of deaths and weeks of deadlock and riots as residents fought for access to water, showed the vulnerability of connected and centrally operated systems, and the need to be able to switch to manual control and isolate system sectors to maintain minimum services; failsafe mechanisms that are slowly still being installed. From a social perspective, the centralised system has been able to guarantee that the poorest can still access (and afford to access) water, including in some places though cross subsidies between customer categories that are implemented through specific pricing schemes and social rebates. From an environmental perspective, the centralized system has typically been able to integrate itself into river basin management planning processes. The size of these urban water monopolies has led to benefits such as having an increased political weight and negotiation power to defend its own interests against farming and environmental lobbies. The up-scaling process has been accompanied by a greater involvement of users in the governance of water systems, especially through the local vertical urban farming movement that has gone head-to-head with traditional rural farmers and global agri-food businesses and pushed for nutrient recycling systems since the 2020s. Despite the general success of these monopolies in providing universal water access and supporting local citizen groups and businesses to engage in food production, there are significant environmental and business protest groups who are unhappy about the power of these monopolies. They believe that they are stifling innovation and alternative low-energy, low environmental impact decentralised technologies that they believe could drive economic growth that has stagnated in many cities and improve environmental quality. Cities are now locked into increasing the concrete, steel and plastic mazes that criss-cross them (which are becoming increasingly costly due to resource competition), rather than being able to develop water system alternatives for new developments and urban renewal projects.

\subsection{Scenario 2 in 2050: System Fragmentation}

This scenario depicts how, by 2020, the production cost of centralised water services had increased tremendously, reflecting the high investments required to meet more stringent global and national environmental objectives (e.g. higher waste water treatment standards and storm water management requirements) and to mobilize scarce water resources in the context of increasing climate variability and change (e.g. desalination, wastewater reuse, rainwater tanks, groundwater bores). At that time the cost recovery principle had been strictly implemented in many areas of the world, resulting in drastic increases in water tariffs, along with an in enshrining of an individual's or businesses' right to water that fell on their property or for which they had purchased an access right and entitlement (e.g. for groundwater). The response of many customers who were able to afford it was to invest in individual or collective decentralised water supply and sanitation systems, bypassing the local or 
urban-wide water utilities. The rejection of the centralised services by increasing numbers of urban residents through the 2020s led to private companies investing significantly in this new market and developing innovative and high quality decentralised water services and systems in wealthy residential and commercial neighbourhoods. However, services to supply the poorest customers dwindled, only sometimes being supported by philanthropy or NGOs in some lucky cases. In the majority of these poorer urban areas or rapidly expanding slums, residents typically rely on low cost connections for use of water at night only or cheap black-market water stolen from wealthier neighbourhoods, illegal connections to the main supply system or agricultural regions. By the early 2030s, most of the remaining public water utilities (except in some countries that threw out the neoliberal economic proposition late last century or earlier this century) have had to almost completely stop investment in the renewal of the distribution network due to declining revenues. This resulted in increasing frequency of breakdowns, lower quality service and further accelerated customer flight to alternative water supply and sanitation options, including bottled water and dry-composting toilets sponsored by agri-food companies who needed the nutrients to replace scarce and costly fertilisers. After years of spiralling downwards and with the threat of bankruptcy and system failure for many utilities, in 2035 an international summit was called to discuss the developing global health crisis linked to the resurgence of cholera and diarrheal-related deaths in developed countries, and widespread social unrest and water-related crime. From this summit the framework was put in place which allowed the four major global agri-food businesses to easily strike agreements with different national and local governments for preferential market access and limits on other companies' access in return for developing water and linked agri-food systems to supply populations. This led to a rapid improvement of poorer citizen's access to water and sanitation but reduced choice of food, with many of the populations from lower socio-economic levels forced to eat the innovative low-cost algae-based "wonder foods" that had been carefully processed to optimise calorie and nutrient intake for cost or opt for the better tasting highly processed junk-food full of high quantities of fat, sugar and salt that had been accelerating the obesity epidemic since last century. In 2050, its now possible to see that inequalities and societal divisions along values-based and socio-economic lines that already existed at the turn of the century have been strongly exacerbated between countries, municipalities and citizen groups, even though this is widely accepted politically in most societies. Yet, there have been substantial uptakes of different types of innovation and niches created for the development of: eco-municipalities with locally produced and recycled water and food and the renewal of traditional ecosystem services through the re-engineering of ecosystems; high-tech havens where individuals can make the most of individual or collective solar-powered desalination plants that take water from the sea-water canals and basins present in many coastal cities (which were constructed in the 2030s following increases in storm surges and sea-level rise) automated food production labs (computers that grow and produce food from stem-cells and basic chemical building blocks) and waste to resources recycling stations; connected community collectives where small businesses provide or work together though social media and crowd-funding on new innovations for pilot testing (e.g. nano-robots for water treatment; algae based polymers for water and sanitation networks) and successful ones are exported with the collective maintaining IP and profits for further innovation grants and start-ups; and competitive fortressed business communities where big-business maintains order and services for its employees by shipping in water in the form of bags or ice-burgs (pulled by tugboats) or tankers over land and sends its waste to slum or degraded districts for processing. 


\subsection{Scenario reflections and conclusions}

What these two imagined scenarios-based on the drivers and current transformations outlined in the earlier parts of the paper-illustrate is that urban water management in the future may not be as simple as it was in the past or appears to be currently. Today, the main uncertainties that confront water managers and impact their decisions in terms of infrastructure dimensioning or phasing of investments include those around future water demands, water resource availability (for example due to climate and competition) and technology costs. Although we are seeing other issues such as social, economic and environmental imperatives influencing some management choices, tomorrow's water managers might have to make decisions which could set in motion radical shifts in term of business models, conceptions of social justice, organisational set-up and trade-offs between environmental, economic and social objectives. They will also need to be prepared to anticipate future evolutions in urban water systems and navigate conflicting systems of political and social values in order to avoid options that too strongly lead to system "lock-in" and failure if the conditions that led to that option being successful change. It is possible that "no regret strategies" if they can be identified may make good first choices, but some kinds of lock-in and system inertia are likely regardless of the chosen paths. Challenges will also remain significant and different between developing countries and the more developed ones, with the need for knowledge and capacity exchange, in particular in the form of technological innovations and management strategies becoming increasingly acute in order to alleviate some of the most significant health and social issues associated with a lack of access to adequate water and sanitation.

One of the intentions of this book is to show that the drivers of change and resulting transitions that are occurring in urban water management are not only related to the choice of water technologies and infrastructure systems but also to organisational configurations, legislation, aid programs, social habits and values, policies, political ideologies and the management of societies. We hope that it provides many insights into this crucial global challenge and inspiration for the creation of more sustainable and resilient societies in the future.

\section{References}

ABS (2002). The influence of lifestyles on environmental pressure, 1301.0 - Year Book Australia, 2002, Australian Bureau of Statistics, Canberra.

Arthur, B.W. (1988). Competing technologies. In: Dosi, G. (ed) Technological change and economic development, Printer, London/New York.

Bai, X., Imura, H. (2001). Towards sustainable urban water resource management: a case study in Tianjin, China. Sustainable Development 9(1): 24-35.

Barraqué, B. (2012). Return of drinking water supply in Paris to public control. Water Policy, 14, 903914. 
Bedu, C. (2010) Quand une citadelle technique se (sou)met à l'épreuve de l'"impératif délibératif ». Récit et analyse pragmatique d'une procédure de type "mini public " dans le domaine de l'eau potable. $\mathrm{PhD}$ thesis, Université de Strasbourg, France.

Brown, R.R., Ashley, R., Farrelly, M.A. (2011) Political and Professional Agency Entrapment: An Agenda for Urban Water Research, Water Resources Management, 25(15): 4037-4050.

Brown, R.R., Farrelly, M.A. (2009). Delivering sustainable urban water management: a review of the hurdles we face. Water Science \& Technology 59(5): 839-846.

Brown, R.R., Keath, N. Wong, T.H.F. (2009). Urban water management in cities: historical, current and future regime. Water Science \& Technology, 59(5): 847-855.

Castro, J.E. (2007). Poverty and citizenship: Sociological perspectives on water services and publicprivate participation. Geoforum, 38, 756-771.

Cleaver, F., Toner, A. (2006). The evolution of community water governance in Uchira, Tanzania: The implications for equality of access, sustainability and effectiveness. Natural Resources Forum 30: 207-218.

Coombes P.J. (2012) Integrated Systems Analysis to Create Evidence Based Policies for Water Cycle Reform in Greater Melbourne. 34th Hydrology and Water Resources Symposium, Engineers Australia, Sydney.

Creighton, J.L. (2005), The public participation handbook: making better decisions through citizen involvement, Jossey-Bass, San Francisco, California, USA.

Daniell, K.A. (2012). Co-engineering and participatory water management: Organisational challenges for water governance. UNESCO International Hydrology Series. Cambridge University Press, Cambridge, UK.

Daniell, K.A. (2013) "Practical responses to water and climate policy implementation challenges", Australian Journal of Water Resources, 17(2): 111-125, http://dx.doi.org/10.7158/W13WC01.2013.17.2.

Daniell, K.A., Coombes, P.J. and White, I. (2014), Politics of innovation in multi-level water governance systems, Journal of Hydrology (under review).

Daniell, T.M, Foley, B.A., Daniell, K.A. (2005) Sustainability in Water Resources Management, Journal of Hydrologic Environment, 1(1): 3-18.

Delli Priscoli, J. and Wolf, A.T. (2009). Managing and Transforming Water Conflicts. Cambridge University Press, Cambridge, UK. 
Dryzek, J. S. (1990). Discursive democracy: Politics, policy and political science. Cambridge University Press, New York.

Dryzek, J. S. (2010). Foundations and frontiers of deliberative governance. Oxford University Press, Oxford, UK.

EU (2000). Directive 2000/60/EC of the European Parliament and of the Council, of 23 October 2000: establishing a framework for Community action in the field of water policy, L 327, 22.12.2000, EN. Official Journal of the European Communities, 1-72.

EU (2002). Guidance on Public Participation in Relation to the Water Framework Directive: Active Involvement, Consultation, and Public Access to Information. Final version after the Water Directors' meeting, December 2002. European Union.

Farrelly, M. and R. Brown (2011). Rethinking urban water management: Experimentation as a way forward? Global Environmental Change, 21: 721-732.

Frederick, K.D., Major, D.C. (1997). Climate change and water resources. Climate Change, 37: 7-23.

Geels, F.W. (2002) Technological transitions as evolutionary reconfiguration processes: a multi-level perspective and a case-study. Research Policy, 31: 1257-1274.

Geels, F.W., (2004). From sectoral systems of innovation to sociotechnical systems. Insights about dynamics and change from sociology and institutional theory, Research Policy, 33: 897-920.

Geels, F.W. (2010). Ontologies, socio-technical transitions (to sustainability), and the multi-level perspective, Research Policy, 39: 495-510.

Geels, F.W., Schot, J. (2007). Typology of sociotechnical transition pathways, Research Policy, 36: 399-417.

Gleick, P.H. (2005). The myth and reality of bottled water. In: Gleick, P.H. (Ed.) The World's Water: The Biennial Report on Freshwater Resources 2004-2005, Island Press, Washington DC.

Godet, M., Roubelat, F. (1996). Creating the future: the use and misuse of scenarios. Long Range Planning, 29, 164-171.

Grafton, R. Q. \& Ward, M. B. (2010). Dynamically efficient urban water policy. Centre for Water Economics, Environment and Policy (CWEEP) Research Paper 2010-13. The Australian National University, Canberra.

Graveline, N., Aunay, B., Fusillier, J.L., Rinaudo, J.D. (2014). Coping with Urban \& Agriculture Water Demand Uncertainty in Water Management Plan Design: the Interest of Participatory Scenario Analysis. Water Resources Management, DOI: 10.1007/s11269-014-0656-5. 
Grant, S.B., Fletcher, T.D., Feldman, D., Saphores, J.-D., Cook, P.L.M., Stewardson, M., Low, K., Burry, K., Hamilton, A.J. (2013). Adapting Urban Water Systems to a Changing Climate: Lessons from the Millennium Drought in Southeast Australia. Environmental Science \& Technology, 47, 1072710734.

Groves, D.G., Lempert, R.J., Knopman, D., Berry, S.H. (2008). Preparing for an uncertain future climate in the Inland Empire. Identifying robust water-management strategies. RAND Corporation, Santa Monica, CA.

Gunderson, L.H., Holling, C.S. (2002). Panarchy: understanding transitions in human and natural systems, Island Press, Washington, DC.

Guy, S., Marvin, S. and Moss, T. (2001). Urban Infrastructure in Transition: Networks, Buildings and Plans, Earthscan, London.

Hallegatte, S. 2009, Strategies to adapt to an uncertain climate change, Global Environmental Change, 19(2): $240-247$.

Hashimoto, T., Stedinger, J., Loucks, D.P. (1982). Reliability, resiliency and vulnerability criteria for water resource system performance evaluation, Water Resources Research, 18:14-20. doi:10.1029/WR018i001p00014

Hargroves, C. and Smith, M. (eds) (2004). The natural advantage of nations: business opportunities, innovation and governance in the 21st century, Earthscan, London.

Hellström, D., Jeppsson, U., Kärrman, E. (2000). A framework for systems analysis of sustainable urban water management. Environmental Impact Assessment Review 20(3): 311-321.

Holland, J.H. (1995). Hidden order: how adaptation builds complexity. Helix books/Perseus Books, Cambridge, Massachusetts.

Holling, C. S. (2004). From complex regions to complex worlds. Ecology and Society, 9(1): 11, http://www.ecologyandsociety.org/vo19/iss1/art11

Hussey, K., Carter, N., Reinhardt, W. (2013). Energy sector transformation: Implications for water governance, Australian Journal of Water Resources, 17(2):170-179, http://dx.doi. org/10.7158/W13025.2013.17.2.

ICWE (1992). The Dublin Statement on Water and Sustainable Development. International Conference on Water and the Environment. Dublin, Ireland.

Jenerette, G.D., Larsen, L. (2006). A global perspective on changing sustainable urban water supplies. Global and Planetary Change, 50: 202-211. 
Kauffman, S. (1995). At home in the universe: the search for laws of complexity. Oxford University Press, Oxford.

Keath, N., Brown, R. (2009). Extreme events: being prepared for the pitfalls with progressing sustainable urban water management. Water Science and Technology, 59:1271-1280.

Larsen, T.A., Gujer, W. (1997). The concept of sustainable urban water management. Water Science and Technology 35(9):3-10.

Lymbery, P., Oakeshott, I. (2014). Farmageddon: the true cost of cheap meat, Bloomsbury, London.

Milman, A., Short, A. (2008). Incorporating resilience into sustainable indicators: An example for the urban water sector. Global Environmental Change 18(4): 758-767.

Mitchell, G.V. (2006). Applying integrated urban water management concepts: A review of Australian experience. Environmental Management 37(5): 589-605.

Montginoul, M., Rinaudo, J.-D. (2011). Controlling households' drilling fever in France: An economic modeling approach. Ecological Economics, 71:140-150.

Muller, M., Simpson, R., van Ginneken, M. (2008). Ways to improve water services by making utilities more accountable to their users: a review. In: World Bank (Ed.), Water Working Notes. World Bank.

Nelson, R.R., Winter, S.G. (1982). An evolutionary theory of economic change. Belknap Press (Harvard University Press), Cambridge, Massachusetts

Niemczynowicz, J. (1999). Urban hydrology and water management - present and future challenges. Urban Water, 1(1):1-14.

NWC (2011). The National Water Initiative - securing Australia's water future: 2011 assessment. National Water Commission (NWC), Canberra.

Ohemeng, F.L.K., Grant, J.K. (2011). Has the Bubble Finally Burst? A Comparative Examination of the Failure of Privatization of Water Services Delivery in Atlanta (USA) and Hamilton (Canada). Journal of Comparative Policy Analysis: Research and Practice, 13: 287-306.

OLV (2013). Melbourne's Water Future. Consultation paper. Office of Living Victoria (OLV), Melbourne.

Pahl-Wostl, C., Sendzimir, J., Jeffrey, P., Aerts, J., Berkamp, G. and Gross, K. (2007). Managing change toward adaptive water management through social learning. Ecology and Society, 12(2): 30.

Palaniappan, M., Gleick, P.H. (2009) Peak Water. In: Gleick P.H. (ed.) The World's Water: The Biennial Report on Freshwater Resources 2008-2009, Island Press, Washington DC. 
Pearson, L., Coggan, A., Proctor, W., Smith, T.F. (2010). A sustainable decision support framework for urban water management. Water Resources Management 24: 363-376.

Plant, R., Maurel, P., Barreteau, O. and Bertacchini, Y. (2014) The Role of Territorial Intelligence: The Case of the Thau Territory, Southern France. In: Squires, V.R., Milner, H.M., Daniell, K.A. (eds.). River Basin Management in the Twenty-first Century: Understanding People and Place. CRC Press, Boca Raton, 446-466

Prigogine, I., Stengers, I. (1984). Order out of chaos: man's new dialogue with nature. New Science Library, Boulder C.O.

Postel, S.L., Thompson, B.H., (2005). Watershed protection: Capturing the benefits of nature's water supply services. Natural Resources Forum, 29: 98-108.

Republic of South Africa (1998). National Water Act, Act no 36 of 1998, Government Gazette, 26 August 1998, Pretoria, Government Printers.

Rockström, J., Steffen, W., Noone, K., Persson, Å., Chapin, F.S. III, Lambin, E., Lenton, T.M., Scheffer, M., Folke, C., Schellnhuber, H., Nykvist, B., De Wit, C.A., Hughes, T., van der Leeuw, S., Rodhe, H., Sörlin, S., Snyder, P.K., Costanza, R., Svedin, U., Falkenmark, M., Karlberg, L., Corell, R.W., Fabry, V.J., Hansen, J., Walker, B., Liverman, D., Richardson, K., Crutzen, P., and Foley, J. (2009) Planetary boundaries:exploring the safe operating space for humanity, Ecology and Society, 14(2): 32. http://www.ecologyandsociety.org/vol14/iss2/art32/

Rogers, E.M. (1983). Diffusion of innovations, Free Press, New York.

Rosenhead, J., Mingers, J. (eds.) (2001) Rational analysis for a problematic world revisited. John Wiley and Sons, Chichester.

Rotmans, J., Kemp, R., van Asselt, M. (2001). More evolution than revolution: Transition management in public policy, Foresight, 3:15-31.

Sabatier, P.A. (1988). An advocacy coalition framework of policy change and the role of policyoriented learning therein, Policy Sciences, 21: 129-168.

Selman, P., Carter, C. Lawrence, A., Morgan, C. (2010) Re-connecting with a neglected river through imaginative engagement. Ecology and Society, 15(3): 18. http://www.ecologyandsociety.org/vol15/iss3/art18/

Smith, A., Stirling, A., Berkhout, F. (2005). The governance of sustainable socio-technical transitions, Research Policy, 34(10):1491-1510.

Smith, A., Voß, J.-P., Grin, J. (2010). Innovation studies and sustainability transitions: The allure of the multi-level perspective and its challenges, Research Policy, 39: 435-448.

Sheehan, M. (2007). 2007 state of the world: Our urban future. Worldwatch Institute, Washington, D.C. 
Squires, V.R., Milner, H.M. and Daniell, K.A. (eds.). River Basin Management in the Twenty-first Century: Understanding People and Place. CRC Press, Boca Raton.

Swyngedouw, E. (2004). Social power and the urbanization of water: Flows of power, Oxford University Press, Oxford.

Tejada-Guibert, José Alberto and Čedo Maksimović (2001). Frontiers in urban water management: Deadlock or hope? Symposium Proceedings, 18-20 June 2001, Marseille, France. IHP-V | Technical Documents in Hydrology, No. 45, UNESCO, Paris.

UNECE (1998). Aarhus Convention on Access to Information, Public Participation in Decision-making, and Access to Justice in Environmental Matters, United Nations Economic Commission for Europe, http://www.unece.org/env/pp/documents/cep43e.pdf

United Nations (2010). A/RES/64/292 The Human Right to Water and Sanitation: United Nations General Assembly.http://www.un.org/waterforlifedecade/human_right_to_water.shtml

UN-WATER (2012). Managing Water Under Uncertainty and Risk. The United Nations World Water Development Report 4. UNESCO, Paris.

van der Brugge, R., Rotmans, J. (2007). Towards transition management of European water resources, Water Resources Management, 21:249-267

Vörösmarty, C.J., Green, P., Salisbury, J., Lammers R.B. (2000). Global water resources: Vulnerability from climate change and population growth. Science, 289(5477): 284-288.

Wenger, C., Hussey, K., Pittock, J. (2013). Living with Floods: Key Lessons from Australia and Abroad, National Climate Change Adaptation Research Facility, Gold Coast.

Whitehead, P.G., Wilby, R.L., Battarbee, R.W., Kernan, M., Wade, A.J. (2009). A review of the potential impacts of climate change on surface water quality. Hydrological Sciences Journal, 54:101123.

Wolff, G.H. and Gleick, P.H. (2002). The soft path for water. In: Gleick, P.H. Burns, W.C.G. Chalecki, E.L. et al. (eds) The World's Water: The Biennial Report on Freshwater Resources 2002-2003, Island Press, Washington DC. 